\title{
Training and in-service training of home economics extension professionals in rural areas of Kwazulu-Natal
}

\author{
Sazile M Mtshali
}

\begin{abstract}
Home economics is traditionally a femaledominated profession. Home economists employed in the KwaZulu-Natal agricultural and rural development extension delivery system are mainly responsible for serving a predominantly female clientele, namely rural women. These home economists focus on women's domestic and reproductive roles, sometimes supplemented by home and community gardening and small livestock care. They also teach incomegenerating skills related to sewing and handicrafts.

In view of the national and provincial policy to put rural women into mainstream agriculture to boost rural economies and sustain adequate food security, this paper makes some suggestions about the reorientation of home economics in-service training programmes. This reorientation should align current training with the gender roles and needs of rural households. Planners of extension delivery services should review preservice training curricula and identify skills gaps through the participatory in-service training of home economics professionals in rural development.
\end{abstract}

- Ms Sazile M Mtshali

Department of Home Economics, University of Zululand

\section{INTRODUCTION}

Statistics and surveys throughout KwaZulu-Natal (KZN) indicate a higher incidence of poverty in rural areas. The human development index (HDI) which expresses the development standard of a community is valued at 0,58 in $\mathrm{KZN}$ compared to provinces such as the Western Cape and Gauteng with an aboveaverage $\mathrm{HDI}$ of 0,76 and 0,71 respectively. Like other provinces with a low $\mathrm{HDI}$ reading such as the Eastern Cape $(0,48)$ and the Northern Province $(0,40), \mathrm{KZN}$ faces challenges to contribute to a sustainable agricultural and rural livelihood (Human Sciences Research Council, 1996:140). Rural households are affected by the prevalent conditions of rising poverty, rapid population growth, increased rural/urban migration, urbanisation, widespread ill-health, illiteracy and high unemployment.

There are almost no opportunities for rural women to earn money to supplement uncertain, irregular remittances from migrant workers. Meagre old-age pension payments are often the only source of income in rural households. In view of limited opportunities and restricted access to employment, rural women continue to be involved in subsistence agricultural production, seasonal and paid agricultural work and nonagricultural activities. Rural women also frequently have little access to agricultural information and extension services.

Meaningful agricultural extension efforts tended to concentrate on small-scale commercial or cash crop production where male farmers predominate. Training with respect to subsistence crops and small livestock, where women farmers predominate, is less common. Most training programmes for women still emphasise domestic skills rather than agricultural skills though both are relevant and need to be combined (KwaZulu-Natal Department of Agriculture, 1998:28). According to the White Paper on Agriculture for KZN (1996: 24-25), the home economics section is required to train staff in "food security, consumerism, family management and economics, affordable home improvement and opportunities for establishing viable home industries".

The complexity, diversity and risk-prone nature of the lives of rural women is frequently ignored by extension professionals (Whiteside, 1998:26). For instance, development planners have assumed that information given to male farmers will be passed

The Training and in-service training of home economics extension professionals in rural areas of Kwazulu-Natal 
along to other farming members of the household. Research has proved that agricultural and rural development knowledge acquired by men seldom "trickles across" effectively to the women in the household (Saito \& Spurling, 1992:18). The appropriateness of agricultural and rural development extension delivery services should therefore be critically examined and home economics extension professionals should be trained and retrained to meet the needs of rural communities.

Extension services are a key link to increasing food production and to transforming rural household economic activities that contribute to livelihood security. Appropriate extension services could influence rural livelihoods, gender roles, functions and needs. Redefining home economics and its general goals, contextualising the content of home economics, describing the skills and competencies that are required to do extension work and training and retraining home economists and agricultural home economists involved in rural development would serve rural women better.

\section{THE RURAL HOUSEHOLD}

The household is defined as "the scene of economic allocation, arranging collectively for food, clothing and shelter of its members, and seeking to provide for these needs over the long term with some measure of security against controllable disruptions of the climate, the market economy and the state" (Netting, 1993:16). Members of a household are often biologically related and share a common residence. The boundaries and composition of the household are subject to continuous change due to changes in the basic economic system, constraints on housing or the redefinition of kinship obligations.

De facto female-headed households are common in rural areas because of the rural/urban migration of men. De jure female-headed households are also prevalent due to widowhood, divorce and desertion. The human immunodeficiency virus (HIV) and acquired immune deficiency syndrome (Aids) have an impact, as families in which one member, often the father, has HIV-Aids also become female-headed. Women with children who never got married also head households. The general structure of these households has an implication for planning appropriate extension training programmes.

\section{ROLES OF WOMEN IN THE HOUSEHOLD}

Analysing the gender division of labour is an effective way of gaining insight into the internal organisation of rural households. Moser (1993:28) discusses women's triple role in rural areas as reproductive, productive, and community management and community politics.

\section{Reproductive work}

The woman's reproductive role entails the childbearing and rearing responsibilities and related domestic tasks undertaken by women. This role guarantees reproduction and maintenance of the labour force. Women are responsible for childcare, maintenance of the husband, and sick and infirm members of the household. Rural women are responsible for all domestic work such as fetching water and fuel, food storage, food processing and preparation, washing and ironing clothes, assisting in building, maintaining and cleaning the house and caring for HIV-Aids patients.

\section{Productive work}

Productive work refers to the work done by both men and women for payment in cash or kind. It includes both market production with an exchange value, and subsistence or home production with an actual use value or a potential exchange value. Productive work usually generates an income. This includes work in both the formal and informal sectors such as a household enterprise. Productive activities include all tasks that contribute to the household and community economies, for example food processing and preparation, handicraft production, marketing and waged employment. Women's productive role is undervalued because no economic value is placed on the work they do in agriculture, the home and informal enterprises.

\section{Community management and community politics}

The community management role involves the collective organisation of social services and events such as serving on committees for rural development, building schools or bridges, health and nutrition programmes, communal gardening, ceremonies and education. Women often volunteer for community management. Men who involve themselves in community politics are sometimes paid in cash or rewarded with power and status. Women and men assume distinct socially and culturally defined responsibilities and tasks, both in the household and the wider community. They consequently tend to have different needs and aspirations.

\section{GENDER NEEDS}

Moser (1993:158) contends that when planning needs are identified, it is important to disaggregate households within communities on the basis of gender and generation in order to describe what men, women, boys and girls are expected to do. Identifying rural women's interests makes it possible to translate them into planning needs (Moser, 1993:38). This author also classifies gender needs into two categories:

Practical gender needs are related to women's reproductive role. These needs are associated with women's caring role in the household and community. 
Practical gender needs are based on the cultural division of labour and women's experiences (Moser, 1993:160). Rural women's basic needs are closely related to their reproductive, productive and community management roles. Practical gender needs are food, shelter, water, health and education. In addition women need a cash income to pay for their households' basic necessities.

Strategic gender needs are those which arise from women's subordination to men. These needs are more abstract as they deal with issues of power and control. Rural women would need capacity to confront the nature of gender inequality (Moser, 1993:39).

Differentiation between gender needs provides a crucial planning tool to determine which knowledge and skills rural women need in view of the focus and content of home economics as a field of study.

\section{THE CONTENT OF HOME ECONOMICS}

At the Lake Placid Conference of 1908, home economics was defined as "the study of laws, conditions, principles and ideals concerned with man's immediate physical environment and his nature as a social being, and especially the relationship between the two for the purpose of improving the quality of his daily life" (Balakrishnan, 1992:3).

In practice the discipline has placed a disproportionate emphasis on training for the reproductive roles of women such as baking, embroidery, child care and household technologies. The revised focus and content of home economics in South Africa define this discipline as "an applied science that focuses on human wellbeing throughout the individual and family life cycle via the assessment, understanding and application of knowledge and skills pertaining to selected aspects of food, clothing and housing as the individual, family, household and group interacts in and with the micro, meso and macroenvironments. Wellbeing refers to the physical, material, social, psychological, aesthetic and cultural wellbeing of individuals, families, households and groups" (Boshoff, 1997:53).

In a rural context, home economics content should be based on the practical and enduring life problems of individuals and households such as food security, clean water and sanitation, adequate housing and clothing, health, nonformal education, gardening and small-livestock care (Engberg, 1994:227). The focus and content of home economics should therefore be based on gender and generation roles in rural households.

When in-service training programmes are planned, planners should take the diversity in rural households into consideration. It is imperative that they have direct knowledge and an understanding of the changing nature of rural households (Food and Agriculture Organisation, 1994:106-107).
Home economics should be utilised more effectively in national development activities. Where appropriate, some agricultural and home economics programmes could join forces to serve rural households effectively (Balakrishnan, 1992:1-4). Redesigning of home economics and agricultural curricula at training institutions would enable extension workers of both sexes to provide appropriate advice and training to rural farmers, especially women, based on their real needs.

\section{NONTRADITIONAL AREAS OF RURAL KNOLWEDGE AND SKILLS}

Food production or subsistence farming as opposed to cash and export crops has always been the responsibility of the women in rural areas. Women are primarily responsible for weeding, harvesting, transporting, storing, processing and marketing produce in the absence of men. They often contribute greatly to ploughing and planting. However, the agricultural activities of women and men vary according to the region, the structure of the household, and the productive resources available (Food and Agricultural Organisation, 1990:14).

Balakrishnan (1992:12) states that the agricultural training of women should be expanded in recognition of their extensive role in agricultural production. Three interfacing areas have been identified in home economics and agricultural training curricula:

- Home economics and agricultural disciplines share the common purpose of improving the resources base of agricultural/rural households.

- Home economics and agricultural disciplines both focus on households and families as a primary resource for organising or analysis/technology interventions.

- The inseparable nature of the production and consumption spheres in agricultural households consequently require a focus on complementary household and family resource dynamics.

At university level, in particular, what is taught to students who are going to work in the field of rural development should be carefully reconsidered. The perspectives of home economics professionals should be broadened, and communication between the fields of agriculture and home economics should be strengthened to encourage the development of curricula that focus on the activities of rural households as resourcegenerating and resource-organising units.

The following are potential areas of interaction between home economics and agriculture, identified by Balakrishnan (1992:12-13):

- A farming systems approach to address farm household production and consumption problems

- Interaction between household resourcegenerating and resource-organising behaviour and the sustainability of ecological resources

- Interaction between pesticide management and rural/agricultural household health 
- Rapid rural appraisal techniques applied to technology transfer and constraints in adopting nonagriculture-related technologies

- Improving the knowledge and skills of development bureaucracies to implement development programmes and to provide production and service input to rural households

- Basic needs indicators to monitor improved living standards due to technology transfer

- Low input food preservation/processing and storage technologies

- Gender roles as a labour dynamics issue in agricultural production systems and consequently in agricultural development

- Integrating relevant human nutrition dimensions in agriculture, forestry, livestock and fishery courses, for example small ruminant production and household nutrition and the impact of vegetable production on community nutrition

- Interaction between rural credit and household financial status and resource management practices.

Bryceson (1995:214) suggests training to support women's enterprises in rural areas. Such training would cover nontraditional skills and knowledge:

- Building skills to improve and maintain living quarters and other functional buildings

- Engineering skills to improve and maintain village infrastructure such as paths, water supply installation, etc.

- Time management to streamline the physical effort expended on agricultural activities and transformation work.

\section{REORIENTATION OF HOME ECONOMICS FOR RURAL SOCIAL DEVELOPMENT AND IN-SERVICE TRAINING FOR HOME ECONOMISTS IN AGRICUL- TURAL EXTENSION}

The main objective of this reorientation of home economics is to train home economists who are sensitive to the agricultural and development needs of rural people. A reoriented programme would train home economists to develop programmes, projects, curriculum content and training and learning experiences that reflect the production and consumption priorities of rural households. More emphasis should be placed on retraining home economists to have a practical orientation and a deep knowledge of the problems of rural households and farming systems.

There is a great need to improve human resources for agriculture and rural development. Home economics reorientation interventions could be put into effect by planning in-service training to update staff's knowledge and skills in a multitechnology approach to rural development. Retraining home economists would require short courses to fill skills gaps in serving rural households effectively.

In-service training could be provided in the following areas:

\section{Gender analysis in agricultural and rural develop- ment extension}

For various reasons agriculture is increasingly managed by rural women in the absence of men. Food production has long been recognised as primarily a woman's work (Boserup, 1980:12). Women are also responsible for all postharvest activities such as food storage, processing, preparation, preservation and marketing. Men's and women's roles in rural communities should be recognised, their activities and the division of labour as well as access to, control and distribution of the available resources. It is significant that the constraints under which men and women operate differ. Gender analysis examines women's participation in decision making, their organisational capacity and their images and self-images.

\section{Research methodologies}

Various research methods exist for data collection relevant to rural sociocultural realities:

- Participatory rural appraisal (PRA), is considered by Chambers (1997:104) as a method for a professional to facilitate a group discussion on relevant issues. Partnership development and sharing of information with rural people take place.

- Participatory action-reflection research (PAR) is an approach that enhances rural people's awareness and confidence.

- Rapid rural appraisal (RRA) enables researchers and extension professionals to gain information on and insight into the circumstances of rural populations.

- Needs assessment facilitates the planning and implementation of appropriate programmes.

- Monitoring and evaluation of programmes are used to assess their impact on rural communities.

\section{Rural livelihood diversity}

The livelihoods of most rural households are diverse and complex. An individual or household gets involved in many livelihood-related activities per year (Chambers, 1997:163-164). Ellis (1999) describes livelihood as "the activities, the assets, and the access that jointly determine the living gained by an individual or household". Rural people tend to diversify portfolios of activities and social support for survival in order to improve their standard of living. Such rural livelihood strategies must be understood in order to plan appropriate programmes.

\section{Appropriate technology for rural women}

Since women are not a homogeneous group, they need a wide range of technologies appropriate to their roles and activities. Rural women need a cash income and nonagricultural employment in rural areas should therefore be created.

Women's access to agricultural resources is limited. They are constrained by lack of land, access to capital, credit, training and markets. Home economists 
frequently involve women in sewing, embroidery, spinning and weaving, baking and other such skills. Projects based on these activities are unrealistic in view of the conditions in rural areas. Rural women do not have enough time and money to attend classes in order to master these skills. Such activities are not traditional among rural women, and are therefore difficult to master. Training in appropriate technology would enable the home economist to be a better resource professional in helping women to improve their quality of life. Examples of appropriate technologies include be labour-saving equipment for water collection, food processing and alternative energy sources.

\section{Income generation}

Research in Africa, Asia and Latin America has established that improvements in household food security and nutrition are associated with women's access to income and their role in household decisions on expenditure. They tend to spend a significantly higher proportion of their income than men on food for the family. Women's purchasing power is important for the household's basic needs such as food, clothing, shelter, health and education. They also need cash to pay for the inputs used in food production. Attention therefore has to be given to increasing their participation in market production and other incomegenerating ventures.

The objective of the reoriented training should be to help rural people, especially women and youth, to earn an income. Training is particularly useful in providing skills to establish a successful small enterprise. A range of skills are needed to run a successful business, including technical and basic business skills such as bookkeeping, marketing and promotion skills. However, the economics of any project should be worked out properly before any income-generating activity is initiated.

The main constraints to generating an income are a lack of appropriate skills and inadequate access to technology, information and credit. Training could relieve each of these constraints. Home economists need accurate information about markets, business management, policies, credit organisations and arrangements, quality-control procedures and suitability of equipment and suppliers. Women should be trained to organise, mobilise and gain access to resources that are otherwise denied them. However, income-generating activities should always build on women's traditional skills and knowledge of handicrafts, agriculture, livestock or technologies.

\section{Nutrition and household food security}

A household's nutritional status is influenced by its access to the appropriate quantity and quality of food, access to wood or other fuel, clean water and food preparation equipment as well as enough time to feed infants and young children. Given women's crucial role in food production and provision, in-service training should address strategies for sustainable nutrition and food security.

Training in appropriate food storage and processing should be a priority to minimise food losses. Food processing and preservation could become one of the most important sources of income and employment in the rural areas of KZN. Rural women process food, especially for household consumption, with little or no modern technology. Training in improved technologies for drying fruit, vegetable and root crops would reduce food losses.

\section{Livestock}

Women are responsible for looking after the household's livestock. They treat the animals for disease. Poultry and small animals such as sheep, goats and in some areas pigs are important to rural women because these animals are frequently the only source of income fully under their control.

It is often assumed that women tend the small animals whereas men own and care for large livestock. This division of labour should not be taken for granted, especially in rural areas where women-headed households are in the majority. In the Bergville and Hlabisa districts the women own cattle and look after them. Training in the care of livestock would benefit women and encourage their participation in livestock extension programmes that are usually dominated by men.

\section{Environmental education}

Providing sustainable rural livelihoods for the present and future generations is critical. Hence rural populations should be supported and educated on caring for the environment. Oduro-Mensah (1992) defines environmental education as "the process of developing in an individual certain attitudes, skills and knowledge that will enable him to interact successfully and live in harmony with the forces and elements that surround him and sustain his life". Rural women play a central role in a community's productive and reproductive activities. They are known as the collectors and managers of agricultural produce, water, forestry and energy resources. When environmental conditions decline, as in deforestation, the women suffer (Elliot, 1994:78). Home economists should have knowledge and an understanding of the environment, causes of its deterioration, and how environmental quality could be improved.

\section{Health education}

A combination of insufficient clean water, inadequate sanitation and malnutrition causes health problems. Home economists in a rural extension delivery system would encounter some of these problems when they promote the production and consumption of food needed in a balanced diet. They could play a critical role in preventive health care if they receive appropriate in-service training.

HIV-Aids has become prevalent in KZN and the rate of 
sufferers is rising rapidly. Aids has had a tremendous impact on the reproductive and productive roles of rural dwellers. If the household is affected by Aids, its capacity to perform its function of ensuring food security is reduced. A lot of money is spent on caring for Aids patients. The contribution of the patient to the household income is reduced and other family members have to carry heavier workloads. The entire household is negatively affected if one of its members contracts HIV/Aids (Kateregga, 1994:20). Home economists in rural areas work at grass-roots level with families and households. In-service training is crucial in enabling extension professionals to deal with households who are affected by HIV/Aids.

\section{Participatory training}

Participatory approaches and practices should be used to train home economists with a view to rural development. Chambers (1997:212; 233) states that training has been didactic rather than participatory. The didactic approach as in lecturing tends to impose knowledge, meaning and values on trainees. Participatory training on the other hand is experiential. It emphasises behaviour and attitudes rather than methods.

Participatory training is a process of learning for people who are engaged in development and social change. It is grounded in participatory research which was developed to elicit practical and effective responses to the harsh realities of underdevelopment. Participatory training is an important methodology with a specific philosophical instance of social transformation through the contribution of knowledge in creating awareness, empowerment and ideas for organised action (Shrivastava, 1989).

Principles of participatory training The content and methodology of participatory training should empower trainees, especially women. Empowerment in this context is a two-way process in which the trainers empower and are empowered (Bhasin, 1992).

Shrivastava (1989) outlines the following primary principles of participatory training:

- This participant-centred training is directed by the specific needs of the participants. The participation of trainees determines content, duration and methods of training.

- Participatory training focuses on awareness, knowledge and skills. Awareness of one's own situation and the overall socioeconomic reality is important.

- Experiential learning is important and relies heavily on the past experiences of trainees. This entails a systematic sharing of trainees' experiences, analysed collectively by the trainees and the trainers.

- A suitable learning environment should be created. Trainees should be accepted as they are, feel psychologically safe to experiment and take risks, enjoy mutual support, and feel confident that whatever happens in training will not be used against them later.

- The training should provide an opportunity to transfer learning to real-life situations. The participants could identify problems in real life that they would like to solve. They could plan solutions and identify new insights during the last phase of the training programme.

- Participatory training is a social process in which the training programme becomes a temporary organisation that follows values, norms and principles that are congruent with the training objectives.

- Participatory training contains group-building processes and interventions. Group development constitutes an important step towards building a suitable learning environment.

- The behaviour of the trainer should be congruent with the aims, values and principles of training. Humility in this regard is important and openness to others' ideas would facilitate participation.

If these principles are followed, an understanding for a participatory training process develops. Shrivastava (1989) believes the following about participatory training:

- Participatory training is based on the assumption that the participants already possess some knowledge.

- New knowledge is built on people's existing knowledge.

- Participatory training emphasises active participation in generating knowledge.

- Participatory training is a collective process of seeking new knowledge.

- It creates informed options as participants are able to accept and reject options on an informed basis.

- Actions emerge from a participative analysis of a given reality as this creates a sense of ownership and willingness to transform the reality.

\section{CONCLUSION}

This article reviewed rural households, gender roles and needs, the content of home economics as an area of study in relation to the agricultural and development needs of rural populations, and some principles in the policy of the White Paper on Agriculture for KwaZulu-Natal (1996). Current issues were discussed relevant to a reorientation of the training and in-service training of home economists for extension services in the Department of Agriculture. Such reorientation of the training curricula would help to reequip home economists to assist in provincial and national rural development efforts that are based on contemporary policies and strategies to alleviate poverty in rural areas.

An important criticism of the home economics programmes in sub-Saharan Africa is that the discipline is burdened with a triple bias of gender, Western and urban cultures. Curricula and training activities ignore rural women's productive role in food production and 
related tasks. The urban bias has undermined the importance of rural households and failed to serve the rural population satisfactorily.

National and provincial policies on agriculture increasingly recognise the need to integrate women in mainstream agricultural and rural development in order to maximise the output of both men and women in agriculture. Women are considered a force for rural change and there is a growing awareness of their role in social and economic development.

Although KZN's agricultural extension policy aims to meet the needs and aspirations of all male and female smallholder farmers, most in-service programmes for women in the Home Economics Division still emphasise domestic skills such as cooking, baking, sewing and knitting rather than agricultural skills.

In implementing the government's policy to bring women into mainstream agriculture, in-service training programmes should be planned to reorient home economics and agricultural extension to focus on women's economic and productive activities. The curricula for in-service training in home economics and agriculture are vital to rural development in $K Z N$. If agriculture, animal husbandry, nutrition and household resources management are included in home economics curricula, and if gender issues are covered in agricultural in-service training, extension professionals of both sexes would be better equipped to advise and train rural farmers - especially women. Knowledge of business management, environmental and health education would benefit both the agricultural and the home economics professional. The economic benefits of participatory training of home economists in rural development extension should become apparent as they pass on their skills and knowledge to their trainees. The multiplier effect should be very powerful.

\section{REFERENCES}

BALAKRISHNAN, R (1992): Reorientation of home economics for rural development in developing countries: a technology transfer training approach. Rome. Food and Agriculture Organisation.

BHASIN, K (1991): Participatory development demands participatory training. Adult Educ Dev 36:3-20. BHASIN, K (1992): Education for women empowerment: some reflections. Adult Educ Dev 39:11-24.

BOSERUP, E (1980): The position of women in economic production and in the household, with special reference to Africa, in Presvelou, C and SpijkersZwart, S. The household, women and agricultural development. Proceedings of a symposium organised by the Department of Home Economics, Agricultural University, Wageningen. January 1979.

BOSHOFF, E (ed) (1997): Focus and content of home economics in South Africa. J Dietet Home Econ 25(1):53-58.

BRYCESON, DF (1995): Wishful thinking: theory and practice of Western donor efforts to raise women's status in rural Africa, in Bryceson, DF. Women wielding the hoe: lessons from rural Africa for feminist theory and development practice. Oxford. Berg.

CHAMBERS, R (1997): Whose reality counts? Putting the first last. London. Intermediate Technology Publications.

ELLIOTT, JA (1994): An introduction to sustainable development: the developing world. London. Routledge.

ELLIS, F (1999): Rural livelihood diversity in developing countries: evidence and policy implications. Overseas Dev Inst 40 (April):1-4.

ENGBERG, LE (1994): Towards reflective problem solving: a promise for home economics, in D' Oyley, V, Blunt, A \& Barnhardt, R. Education and development: lessons from the Third World. Calgary. Detselig Enterprises.

FOOD AND AGRICULTURE ORGANISATION OF THE UNITED NATIONS (1990): Women in agricultural development: FAO's plan of action. Rome.

FOOD AND AGRICULTURE ORGANISATION OF THE UNITED NATIONS (1994): Rural households and sustainability: integrating environmental and gender concerns into home economics curricula. Rome. HUMAN SCIENCES RESEARCH COUNCIL (1996): A socio-economic atlas of South Africa: a demographic, socio-economic and cultural profile of South Africa. Pretoria. HSRC Publishers.

KATEREGGA, CN (1994): Impact of HIV/AIDS on families: the role of the home economics profession, in Van Wyk, R. Women, families and environment. Proceedings of the Second All Africa Conference and First General Assembly, August 17-21 1993, Harare International Conference Centre, Harare, Zimbabwe. Nairobi: Home Economics Association for Africa.

KWAZULU-NATAL DEPARTMENT OF AGRICULTURE (1996): White Paper on Agriculture for KwaZulu-Natal. Pietermaritzburg.

KWAZULU-NATAL DEPARTMENT OF AGRICULTURE (1998): Courses currently being used for inservice training. Pietermaritzburg.

MOSER, CON (1993): Gender planning and development: theory, practice and training. London. Routledge.

NETTING, R McC (1993): Smallholders, householders: farm families and the ecology of intensive, sustainable agriculture. Stanford. Stanford University Press.

ODURO-MENSAH, D (1992): Environmental education and awareness creation through adult education suggestions from Ghana. Adult Educ Dev 39:251260.

SAITO, KA \& SPURLING, D (1992): Developing agricultural extension for women farmers. World Bank Discussion Paper No 156. Washington, DC. World Bank.

SHRIVASTAVA, O (1989): Participatory training: some philosophical and methodological dimensions. Adult Educ Dev 32:3-21.

WHITESIDE, M (1998): Living farms: encouraging sustainable smallholder agriculture in Southern Africa. London. Earthscan Publications. 